\title{
Matematinis modeliavimas - energetikos strateginio planavimo pagrindas
}

\section{Vaclovas Miškinis, \\ Arvydas Galinis,}

Inga Konstantinavičiūtè,

Vidas Lekavičius,

Dalius Tarvydas

Lietuvos energetikos institutas, Energetikos kompleksiniu tyrimu laboratorija, Breslaujos g. 3, LT-44403 Kaunas El.paštas Vaclovas.Miskinis@lei.lt
Rengiant Lietuvai reikšmingus energetikos sektoriaus perspektyvinès plètros projektus ir strateginius dokumentus, labai svarbu ịvairiapusiškai išnagrinèti energijos naudojimo ūkio šakose kaitos tendencijas, numatyti racionalius perspektyvinius energijos poreikius taikant modernius energetikos planavimo metodus ir matematinius modelius, pagrịsti racionalias energetikos sektoriaus raidos ir funkcionavimo kryptis. Straipsnio tikslas - apibendrinti Energetikos kompleksinių tyrimų laboratorijoje sukauptą mokslinių energetikos perspektyvinio planavimo tyrimų patirtị, pateikti reikšmingiausių vykdytų tyrimų apžvalgą, atskleisti matematinio modeliavimo vaidmeni energetikos strateginio planavimo sistemoje formuojant šalies energetikos politiką, išryškinant ir nustatant Lietuvos energetikos sektoriaus raidos ir funkcionavimo kryptis, geriausiai atitinkančias visuomenès lūkesčius, ambicingus ES energetikai keliamus tikslus ir globalius iššǔkius.

Raktažodžiai: matematinis modeliavimas, energetikos sektoriaus raida, strateginis energetikos planavimas, galutinè energija, energijos poreikių prognozavimas, energetikos politika

\section{IVADAS}

Energetikos sektorius - labai svarbi modernios šalies ekonomikos sudedamoji dalis ir sudètinga ūkio šaka, turinti daug įtakos valstybès ekonomikos raidai, jos augimo spartai, visuomenès gerovei. Energetikos paskirtis - užtikrinti energijos išsteklių, jų tiekimo būdų ịvairovę ir patikimumą, veiksmingą gamtinių energijos išteklių perdirbimą i vartotojams labiau tinkamas kuro rūšis, šių išteklių transformavimą i elektros energiją ir centralizuotai tiekiamą šilumą, taip pat ịvairių energijos rūšių prieinamumą vartotojams tinkamu laiku ir priimtinomis kainomis. Todèl energe- tikos sektoriaus plètros kryptys turi būti pagrịstos išsamia ir nuoseklia visų galimų energijos srautų analize, pradedant visų realiai galimų išteklių importu ar jų gavyba šalies teritorijoje ir baigiant šių išteklių ir / arba iš jų pagamintų atskirų energijos rūšiu panaudojimu visuomenès poreikiams tenkinti, racionaliai panaudojant visas esamas technologijas, o ypač efektyviai integruojant naujas, potencialiai galimas, atsinaujinančius išteklius naudojančias ir kitas ateities technologijas, konkurencingas energijos rinkose.

Dèl energetikos sektoriaus specifikos (inertiškumo, modernizavimui ir plètrai reikalingų didelių investicijų, globalių veiksnių įtakos ir gamtosaugos 
bei kitų ribojimų) pasikeitimai vyksta palyginti lètai, tačiau priimamų sprendimų itaka tiek atskirų energetikos sistemų raidai ir funkcionavimui, tiek ir šalies ekonomikai yra ilgalaikè ir tęsiasi dešimtmečius. Todèl energetikos perspektyvinis planavimas turi būti pagrịstas kompleksiniu strateginiu požiūriu nagrinèjant gerokai ilgesni nei politinis ciklas laikotarpi.

Kompleksinis energetikos sektoriaus matematinis modeliavimas yra būtina sąlyga siekiant ìvairiapusiškai nustatyti strategines energetikos sektoriaus raidos ir funkcionavimo kryptis, apibrèžti perspektyvinius energijos išteklių poreikius ir jų racionalią struktūrą, esamų ir ateities technologijų idiegimo apimtis ir terminus, priimtinas investicijų apimtis, pirminès ir galutinès energijos kaitos tendencijas artimoje ir ilgalaikeje perspektyvoje, kad ịvairiais motyvais, įskaitant siekị padidinti šalies energetinị saugumą, pagrindžiamų energijos išteklių visuma patenkintų šalies vartotojų poreikius mažiausiomis sąnaudomis, taip pat ir mažiausiomis energijos kainomis galutiniams vartotojams. Naujus iššūkius energetikos sektoriaus raidos ir funkcionavimo modeliavimui kelia reikšmingi pokyčiai energijos rinkose, susiję su naujų pajègumų, generuojančių elektrą ir šilumą iš atsinaujinančių energijos išteklių, integravimu, poreikiu išplètoti nacionalinius tyrimus $\mathfrak{i}$ regioninit lygmenį, modeliuoti energetikos poveiki makroekonomikai ir pan. Matematinio modeliavimo vaidmuo taip pat labai svarbus siekiant pagristi energetikos raidos strategines nuostatas, gerai derančias su ambicingais Europos Sajungos (ES) klimato kaitos švelninimo tikslais, tenkinančias energetikos politiką apibrèžiančių direktyvų reikalavimus ir nepažeidžiančias prisiimtų tarptautinių Lietuvos issipareigojimų.

Straipsnio tikslas - apibūdinti energetikos perspektyvinio planavimo metodinius principus, akcentuoti per pastarąji dešimtmeti išplètotus tyrimų metodus ir naujai sukurtus matematinius modelius, pateikti reikšmingiausių vykdytų tyrimų apžvalgą, atskleisti šių tyrimų vaidmenį kuriant energetikos sektoriaus strateginio planavimo sistemą, formuojant šalies energetikos politiką, išryškinant ir pagrindžiant racionalias Lietuvos energetikos sektoriaus raidos ir funkcionavimo kryptis, kurios geriausiai atitinka globalias tendencijas ir visuomenès lūkesčius.

\section{METODINIAI ANALIZĖS PRINCIPAI}

Pagrindiniai energetikos sektoriaus raidos mokslinių tyrimų etapai, kurie taikomi Lietuvos energetikos instituto Energetikos kompleksinių tyrimu laboratorijoje ir apibendrinti [1-3], iš esmès atitinka klasikinę tyrimų schemą: 1) šalies ekonomikos raidos ir galutinès energijos naudojimo ūkio šakose tendencijų analize, perspektyvinių energijos poreikių prognozavimas, 2) atskirų energetikos sistemų esamos būklès analizè, esamų, modernizuojamų ir galimų modernių technologijų techninių-ekonominių rodiklių ịvertinimas, adekvačiu matematinių modelių parengimas, energetikos sektoriaus raidos optimizavimas atsižvelgiant $\mathfrak{i}$ aplinkosaugos reikalavimus ir šalies tarptautinius ịsipareigojimus.

\section{Galutinès energijos poreikių prognozavimas}

Rengiant šalies energetikos ir ekonomikos plètros strategijas, planuojant investicijų politiką, pagrindžiant naujų technologijų diegimo tikslingumą, reikia turèti pakankamai informacijos apie įvairių energijos rūšių sąnaudas ir jų kaitos tendencijas. Šiam tikslui galima pasitelkti šalies energijos balansus, kuriuose pateikiama informacija apie ùkio šakose naudojamų energijos išteklių gamybą, eksportą, importą, atsargų pokyti, detalizuojant ịvairių energijos rūšių sąnaudas pagal paskirtị (elektros energijai ir šilumai gaminti, perdirbti i kitas rūšis, neenergetinèms reikmèms) ir pagal vartotojų sektorius. Šių duomenų ir ypač galutinès energijos naudojimo ūkio šakose analizè yra labai svarbi energijos poreikių prognozems, kurios rengiamos pasitelkiant imitacinius ir ekonometrinius prognozavimo modelius, neapibrèžtumų analizès bei kitus metodus. Esminiai ịvairių prognozavimo modelių taikymo principai, ịvertinant jų ypatumus pereinamosios ekonomikos šalių specifikai ir konkretiems perspektyvinio planavimo uždaviniams spręsti, apibendrinti $[2,4,5]$.

Energijos sąnaudų kaitos analizei tarnauja kiekvienos kuro ir energijos rūšies srautų pokyčius atspindintys duomenys, pradedant jų gavyba (gamyba) ir baigiant galutiniu sunaudojimu vartotojų i̇renginiuose, kurie griežtai ir nuosekliai fiksuojami metiniuose energijos balansuose. Šis principas užtikrina, kad bendrosiose šalies vidaus energijos sąnaudose iqvertinamas ne tik tas energijos kiekis, kuri sunaudoja galutiniai 
vartotojai, bet ir neišvengiami pirminès energijos ištekliu praradimai kuro pakeitimo ir energijos transformavimo sektoriuje, patiriami gaminant elektros energiją, centralizuotai tiekiamą šilumą, naftos produktus, durpių briketus ir pan.

Pagal tarptautinių organizacijų, rengiančių apibendrintus energijos balansus, metodinius principus daugiausia dèmesio šiame etape skiriama galutinès energijos sunaudojimo tendencijų analizei. Galutine energija vadinama ta pirminès energijos išteklių (akmens anglių, gamtinių dujų, naftos ir kt.) ir antrinès energijos išteklių (elektros energijos, naftos produktų, centralizuotai tiekiamos šilumos ir kt.) dalis, kurią tiesiogiai savo įrenginiuose sunaudoja galutiniai vartotojai (pramonés, žemès ūkio, transporto ir prekybos bei paslaugų sektoriaus įmonès, individualūs vartotojai ir pan.). Galutinès energijos sąnaudų ūkio šakose ir ekonomikos raidą apibrèžiančių rodiklių sąsajos yra esminè informacija tiek taikant imitacini MAED modeli, tiek ir ekonometrinius bei kitus poreikių prognozavimo modelius.

Apskritai energijos poreikių kitimui didelès ittakos turi daugelis veiksnių, iš jų: makroekonominių rodiklių (bendrojo vidaus produkto (BVP) augimas, ūkio šakų struktūros kaita ir pan.) kitimas, kuro ir energijos kainų augimas, vartotojų reakcija i pajamų ir energijos kainų augimą, energijos vartojimo efektyvumo didinimas ir kt. Perspektyviniai energijos poreikiai bet kuriuo metu gali būti aprašomi kaip funkcija, kuri apibrèžia energijos naudojimo ryšius su pagrindiniais jų kitimą lemiančiais veiksniais. Siekiant korektiškai ìvertinti ekonomikos augimo ir energijos sąnaudų tarpusavio ryšius, prognozės rengiamos remiantis arba išsamia šalies ūkio šakose sunaudojamos galutinès energijos, arba atskirų jos komponenčiu (elektros energijos, centralizuotai tiekiamos šilumos ir tiesiogiai galutinių vartotojų ịrenginiuose sunaudojamo kuro) elastingumo rodiklių už galimai ilgesnị laikotarpị analize ir palyginamąja ịvairių rodiklių bei jų kaitos tendencijų kitose šalyse analize.

Rengiant naujausias perspektyvinių energijos poreikiu prognozes, buvo atnaujinta prognozavimo metodika taikant šiuos bendrus principus: 1) prognozė pagrindžiama išsamia elektros energijos, centralizuotai tiekiamos šilumos ir tiesiogiai ūkio šakose suvartojamo kuro esamos būklès ir kaitos tendencijų analize, įvertinant energijos taupymo galimybes konkrečiose ūkio šakose, ir pasirinktų ekonomikos raidos scenarijų prielaidomis, 2) kiekviena galutinès energijos komponentè modeliuojama atskirai.

Prognozavimui taikant matematinius modelius, labai svarbu tinkamai ịvertinti energijos vartojimo efektyvumo didinimo potencialą. Šiam tikslui gali pasitarnauti tiek ịvairiapuse galutinès energijos intensyvumo rodiklių lyginamoji analizè, tiek ir lyginamųuc energijos naudojimo ES šalyse rodiklių kitimo tendencijų įvertinimas [6-9]. Aktyvi ES energetikos politika ir įvairiose direktyvose nustatyti ambicingi tikslai [10-12] ipareigoja tyrejjus labiau išgvildenti realias ES šalių narių galimybes nuosekliai didinti energijos naudojimo efektyvumą ir numatyti priemones keliamiems tikslams pasiekti.

Rengiant perspektyvinių energijos poreikių prognozes studijose, skirtose Nacionalinès energetikos strategijai atnaujinti $[13,14]$, taikyta nauja namų ūkiuose patalpoms šildyti sunaudojamos centralizuotai tiekiamos šilumos ir tiesiogiai sunaudojamo kuro taupymo efekto įvertinimo koncepcija. Galutinių vartotojų galimos šilumos ir kuro sutaupymo apimtys pagrindžiamos: 1) išsamia faktinių šioms reikmėms sunaudojamos energijos lyginamųjų rodiklių, kurie senos statybos pastatuose su prasta šilumine izoliacija yra keletą kartų didesni nei naujos statybos ir renovuotuose pastatuose, analize, 2) prielaidomis apie gyvenamųjų namų ir visuomeninių pastatų bei jų vidaus šildymo sistemų atnaujinimo apimtis ir spartą. Tokia analizè suteikia galimybę konkretizuoti prielaidas apie siektiną energijos naudojimo efektyvumo didinimo potencialą ir planuojamas pastatų atnaujinimo apimtis.

\section{Energetikos sektoriaus raidos optimizavimas}

Kompleksinis energetikos sektoriaus modeliavimas yra esminè sąlyga siekiant pagrịstai nustatyti strategines sektoriaus raidos kryptis, galimus pirminès energijos išteklių poreikius ir struktūrą, veiksmingiausių technologijų įdiegimo apimtis ir terminus, racionalias investicijų apimtis, pirminès energijos kaitos tendencijas ilgalaikeje perspektyvoje. Svarbiausias optimizacinių skaičiavimų rezultatas - ìvairiais motyvais pagrindžiama tokia energetikos technologijų ir energijos išteklių visuma, kuri patenkina šalies vartotojų poreikius mažiausiomis sąnaudomis. Taip užtikrinamos ir 
mažiausios energijos kainos galutiniams vartotojams nepažeidžiant ES direktyvų reikalavimų, prisiimtų tarptautinių Lietuvos įsipareigojimų ir atsižvelgiant $\mathfrak{i}$ nustatytus šalies energetikos strateginius tikslus bei siektinus šalies energetinio saugumo reikalavimus. Būtent išsamus energetikos sektoriaus perspektyvinès raidos modeliavimas yra būtinas energetinio saugumo naratyvinès analizès būdas, leidžiantis ne tik ịvertinti su energetiniu saugumu susijusių objektų itaką atskirose energetikos sistemose ir jose patiriamus kaštus, bet ir pasiūlyti kvantifikuojamus visuomenès interesus geriausiai atitinkančias energetinio saugumo užtikrinimo priemones.

Šalies energetikos sektorius apima sudètingas tarpusavyje susijusias sistemas (elektros energetikos, dujų, naftos, centralizuoto šilumos ir kitų energijos rūšiu tiekimo), kurias sudaro visuma i̇monių ir ịrenginių, skirtų ịvairių energijos rūšių gavybai, gamybai, transformavimui, perdavimui, skirstymui ir tiekimui galutiniams vartotojams. Tik nuosekliai analizuojant visus galimus energijos išteklius, pradedant jų gavyba ar importu ir baigiant šiu išteklių panaudojimu vartotojų įrenginiuose, galima nustatyti optimalią efektyviausių technologijų sudetti ir kiekvienos energijos išteklių rūšies panaudojimo apimtis Lietuvoje bei jų kaitą nagrinėjamuoju laikotarpiu, pagrindžiant ekonominiu, aplinkosaugos, socialiniu ir kitais aspektais.

Tokiai nuodugniai energetikos sektoriaus raidos ir funkcionavimo analizei pasitelkiami specializuoti matematiniai modeliai, kurie realizuoti taikant MESSAGE, TIMES ar kitus panašius programinius paketus. Naudojami matematiniai modeliai, atsižvelgiant $\mathfrak{i}$ sprendžiamus uždavinius, tarpusavyje gali labai smarkiai skirtis. Esminis bendras tokių modelių principas - galimybė visas energetikos technologijas, tiek esamas, tiek naujai diegiamas, betarpiškai įtraukti ị energijos tiekimo grandinę, taip suformuojant perteklines energetikos technologiju aibes atskirose energijos tiekimo grandinès segmentuose. Optimizacinio proceso eigoje iš perteklinių technologijų aibių suformuojami pasirinkto kriterijaus atžvilgiu optimalūs technologijų poaibiai, tenkinantys galutinių vartotojų ịvairių rūšių energijos poreikius, nepažeidžiant nustatytų reikalavimų (energetinio saugumo, aplinkosaugos, energetikos politikos ir kt.).

Energetikos sektoriui ar atskiroms energetikos sistemoms planuoti ilgoje laiko perspektyvoje
Energetikos kompleksinių tyrimų laboratorijoje taikomas Tarptautiniame sisteminès analizès institute sukurtas matematinio modeliavimo paketas MESSAGE [15]. Jo pagrindiniai principai, energijos balanso, energijos išteklių gavybos, poreikių tenkinimo, energijos ir galių sąryšio, technologijų skverbimosi ị rinką ir kitų modelio lygčių ypatumai bei Lietuvos energetikos institute sukaupta modeliavimo patirtis apibendrinta $[2,16]$. Didelès šio modelio galimybès apimties prasme ir jo lankstumas sudaro palankias prielaidas parengti ir taikyti įvairias šio modelio versijas, tinkančias labai plačiam sprendžiamų uždavinių spektrui.

Remiantis ilgamete patirtimi, laboratorijoje suformuota tokiai analizei keliamus reikalavimus atitinkanti energetikos sektoriaus perspektyvinès raidos ir funkcionavimo analizès matematinio modelio struktūra, kuri suteikia galimybę tyrejjui kompleksiškai modeliuoti atskiras energetikos sistemas, įvertinant esminius vidaus ir išorès ryšius, energetikos politikos nuostatas, aplinkosaugos ribojimus ir kitus išorès veiksnius (1 pav.).

Energetikos kompleksinių tyrimų laboratorijoje pastarajj dešimtmeti parengta daugiau kaip dešimt matematinių modelių, kuriuose įvairiems uždaviniams spręsti buvo taikytas MESSAGE matematinio modeliavimo programinis paketas. Parengti modeliai buvo taikyti konkrečioms problemoms spręsti, pakankamai adekvačiai aprašè šalies energetikos sektoriaus ar atskirų energetikos sistemų raidą ir funkcionavimą ilgalaikejje perspektyvoje. Tokių modelių apimtys dažnai viršija milijoną lygčių ir panašų skaičių kintamųjų. Net ir galingi kompiuteriai tokius optimizacinius uždavinius gali išspręsti tik per kelias ar kelias dešimtis valandų.

Matematinių modelių atnaujinimą metodiniu požiūriu ir naujų modelių kūrimo poreikị lèmé ambicingi tyrejjų tikslai siekiant: 1) užtikrinti energetikos sektoriaus, atskirų energetikos sistemų ar konkrečiu procesų aprašymo adekvatumą, 2) parengti metodologiją, igalinančią analizuoti ir nustatyti optimalią ateities technologijų integravimo $\mathfrak{i}$ energetikos sektorių strategiją ívertinant šalies ir atskirų jos regionų specifiką, 3) atlikti nuodugnią šalies energetikos sektoriaus analizę strateginèms raidos ir funkcionavimo kryptims pagrịsti ir sukurti pagrindus ilgalaikio strateginio planavimo sistemai. 


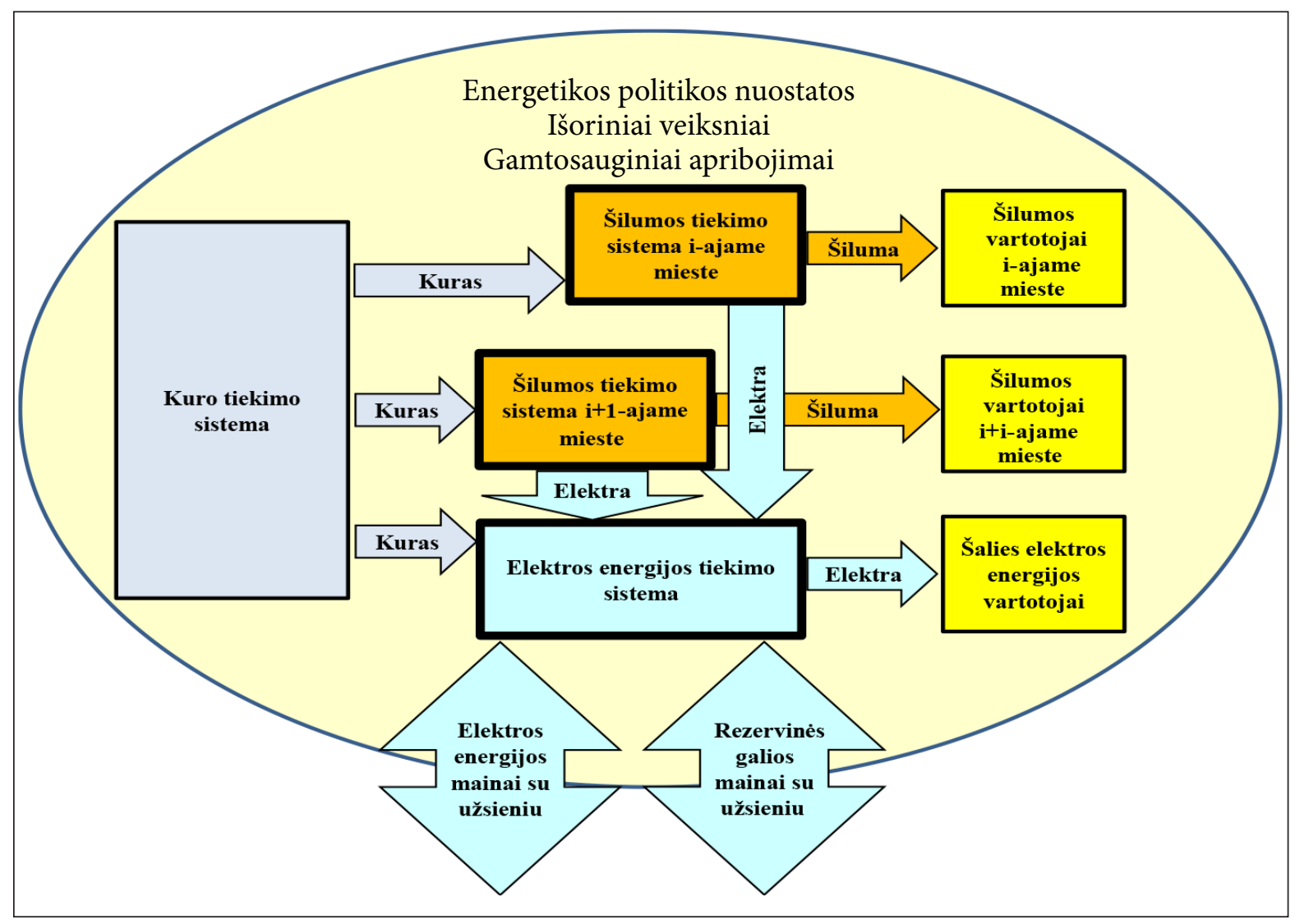

1 pav. Energetikos sektoriaus perspektyvinès raidos ir funkcionavimo analizės matematinio modelio struktūra ir funkciniai ryšiai

Ateities energetikos technologijų integravimas ị energetikos sektorių. Naujų energetikos technologijų integravimas ị šalies energetikos sektorių reikalauja didelių investicijų tiek pačioms technologijoms įdiegti, tiek su jomis susijusiai infrastruktūrai plètoti. Dažnai energetikos objektų techninio tarnavimo laikas, kaip ir investicijų atsipirkimo laikotarpis, yra ilgas. Investicijos $\mathfrak{i}$ energetikos objektus ir technologijas mažina vartojimo galimybes einamuoju laikotarpiu, mažina investicinių lèšų i kitus ūkio sektorius apimtis ir taip keičia dabartinès ir ateities kartų vartojimo galimybes. Energija yra svarbus gamybinis veiksnys, o jos stygius neigiamai veikia šalies ekonomikos augimą. Siekiant korektiškai ịvertinti ilgalaikių investicijų, užtikrinančių spartesni šalies ekonomikos augimą, panaudojimo kryptis, nustatyti energijos išteklių naudojimo apimtis ir atskirų jų rūšių dali perspektyvinio energijos balanso struktūroje, esamų ir naujų technologijų indèli, studijoje [17] buvo parengta metodologija energetikos ir ekonomikos tarpusavio sąsajoms įvertinti, modeliuojant energetikos sektoriaus raidą.
Energetikos sektoriaus plètra turi reikšmingos itakos prekybai su užsienio šalimis, šalies mokèjimų balansui, gamtinei aplinkai, mokslo tiriamiesiems darbams ir kt. Todèl energetikos sektorius turètų būti plètojamas ir naujos technologijos ìdiegiamos taip, kad ši plètra ne tik netrukdytų, bet ir stimuliuotų šalies ekonomikos augimą. Optimaliai tarpusavyje suderinus energetikos ir kitu ekonomikos sektorių veiklą, per ilgą laikotarpi galima pasiekti šalyje maksimalią diskontuotą socialinę gerovę, išreiškiamą lygtimi:

$$
F=W=\int_{\tau_{1}}^{\tau_{2}} e^{-\rho t} U(D(t)) d t \rightarrow \max ,
$$

čia: $F$ - skaliarinè tikslo funkcija, $W$ - skaliarinis gerovès matas, $U$ - gerovés funkcija, $D(t)$ - gerovę nusakančių kriterijų (kintamųjų) vektorius, $\rho$ - diskonto norma, $\tau_{1}$ ir $\tau_{2}$ - nagrinejamojo laikotarpio pradžia ir pabaiga. Nagrinèjamas laikotarpis $T=\tau_{2}-\tau_{1}$ turètų būti pakankamai ilgas (30-50 metų ir ilgesnis), kad būtų galima ịvertinti naujų technologijų eksploatavimo efektyvumą, o 
vartojimo nebūtų galima laikinai padidinti kapitalo nudèvèjimo sąskaita.

Apskritai socialinè gerové yra labai plati ir sunkiai išmatuojama sąvoka, o (1) lygtis yra daugiakriterinè tikslo funkcija. Kriterijų pasirinkimas priklauso nuo to, kaip suprantama gerove ir nemaža dalimi nuo to, kiek jos užtikrinimui, pavyzdžiui, asmeniniam ir visuomeniniam vartojimui, galima skirti lèšų iš šalies bendrojo vidaus produkto.

Atsižvelgiant $\mathfrak{i}$ galimas energetikos sektoriaus plètros ir funkcionavimo matematinio modelio apimtis ir jo ryšiu su ekonomikos modeliu užtikrinimo būdus, studijoje [17] tokiai analizei skirtą energetikos sektoriaus raidos modeli rekomenduojama formuoti blokiniu principu, turinčiu technologinę ir teritorinę dimensijas. Atskiruose modelio blokuose modeliuojamos pirminès energijos išteklių tiekimo sistemos, šių išteklių konvertavimo ị antrinès energijos rūšis sistemos, energijos vartojimo efektyvumo didinimo atskiruose sektoriuose priemonès ir kt. Naudojantis ta pačia modelio duomenų baze, galima generuoti skirtingo agregavimo lygio sistemas, reprezentuojamas atskiruose modelio blokuose. Tai leidžia vieną ar kelias nagrinejjamas sistemas modeliuoti gana išsamiai, o kitos sistemos, kurių raidos analizei skiriama mažiau dèmesio, gali būti reprezentuojamos agreguotai.
Energetikos sektoriaus modeliavimo platesnis poveikis. Energetikos sektoriaus raidos ir funkcionavimo ilgalaikeje perspektyvoje analizè susiduria su globalizacijos, rinkų integracijos, neatidèliotinais klimato kaitos švelninimo ir kitais iššūkiais, kurie išplečia bendrą tyrimų aprèpti (2 pav.):

- ívairiapusé energetikos sektoriaus bendro konteksto analizè, ivertinanti geopolitinius aspektus, tikètinas energijos naudojimo tendencijas, siekius maksimaliai padidinti energijos naudojimo efektyvumą, teisinès aplinkos pokyčius ir pan.;

- energetikos platesnio poveikio tyrimai, akcentuojantys gilesnius energetinio saugumo, energetikos ir ekonomikos sąsajų bei išorinių ekonominių efektų, taip pat ir aplinkosaugos ribojimų tyrimus;

- energetikos sektoriaus raidos ir funkcionavimo modeliavimas ir svarbiausius valstybès tikslus bei interesus atitinkančių strategijų formavimas.

Toks energetikos sektoriaus raidos modeliavimo principas pasižymi įvairiapusiškumu, kompleksiškumu, universalumu ir leidžia nuodugniai analizuoti ir sudaryti prielaidas subalansuotai atskirų šalies energetikos sistemų plètrai įvertinant jų poveikị šalies ekonomikai.

Energetikos ir ekonomikos sąsajų modeliavimas. Energetikos sektoriaus raida yra susijusi ne

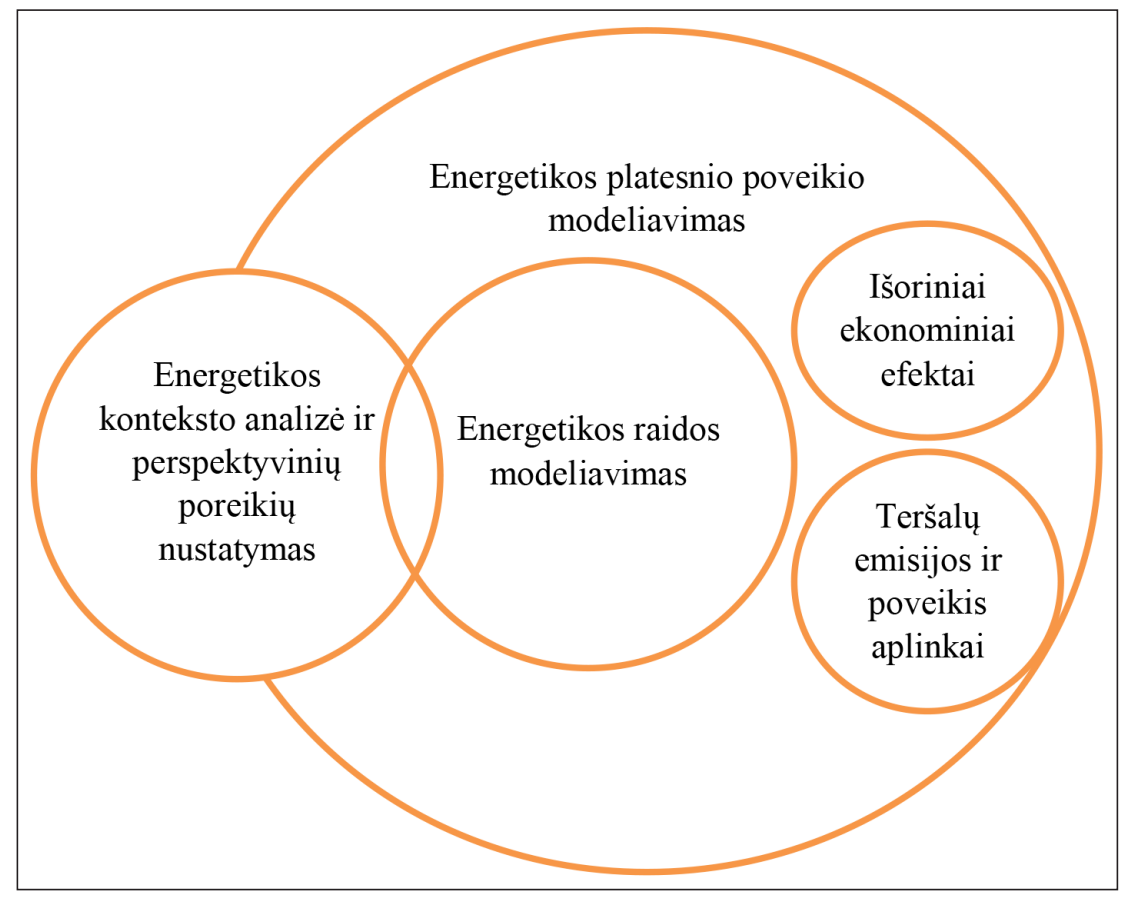

2 pav. Energetikos sektoriaus raidos modeliavimo aprèptis 
tik su energijos transformavimo technologijomis, jų elgsena energetikoje ir poveikiu energijos produktų kainoms, bet ir su platesniais efektais, turinčiais įtakos visam šalies ūkiui (3 pav.). I tokius efektus būtina atsižvelgti tiek nustatant strategines energetikos raidos kryptis, tiek ir formuojant energetikos politiką.

Šie efektai reikšmingai priklauso ir nuo energetikos (generuojančiu technologiju, energijos tiekimo infrastruktūros), ir nuo ekonomikos struktūros. Energetikos struktūra lemia, kokie ištekliai yra naudojami energetikoje siekiant pagaminti ir patiekti vartotojams energiją, o ekonomikos struktūra apibūdina energijos naudojimą, tarpsektorinius ryšius ir kitus veiksnius, lemiančius socialinių ir makroekonominių efektų formavimąsi. Šių efektų vertinimas yra gana sudètingas uždavinys, kurio sprendimą [18] rekomenduojama atlikti pagal 4 pav. pateiktą schemą:

Šiam uždaviniui spręsti pirmą kartą Lietuvoje buvo sukurtas originalus dinaminis bendrosios pusiausvyros modelis. Jis apima 4 energetikos produktus, 19 kitų produktų ir ekonominès veiklos rūšių, įmonių, valdžios ir namų ūkių sektorius bei užsienio prekybą. Modelyje agreguotai atspindima mokesčių sistema ir kitos transakcijos, įskaitant socialinio draudimo įmokas. Išskirtiniai modelio ypatumai - detaliai modeliuojamas elektros energijos, centralizuotai tiekiamos šilumos, gamtinių dujų ir biokuro naudojimas ūkio šakose ir galutinio vartojimo segmentuose; kintamoji energetikos produktų gamybos dedamoji modeliuojama taikant koeficientus, apibūdinančius energetikos produktų kaštų struktūrą kiekvienais nagrinejjamais metais; itin daug demesio skiriama energetikos infrastruktūrai modeliuoti. Praktiniam modelio taikymui sékmingai pasitarnavo sukurti pradinių duomenų ir rezultatų apdorojimo irankiai.

Taikant sukurtąji modeli ịvertintas Lietuvos energetikos raidos scenarijų socialinis ir makroekonominis poveikis laikotarpiu iki 2050 m., apimantis itaką ūkio šakose sukuriamai pridètinei vertei ir bendrajam vidaus produktui, ịvairių rūšių mokesčiams, socialinio draudimo įmokoms ir tarptautinei prekybai [19].

Energetikos sektoriaus poveikio aplinkai vertinimas. Energetikos sektorius neabejotinai turi dideli poveikị aplinkai. Nors Lietuvoje ị atmosferą išmetama palyginti nedidelis šiltnamio reiškinị sukeliančių dujų kiekis, šalies indèlis yra svarbus bendriems ES siekiams švelninti klimato kaitos pasekmes ir stabilizuoti šiltnamio dujų koncentraciją atmosferoje taip, kad 2050 m. nebūtų viršyta jų riba, apibrèžiama 550 ppm $\mathrm{CO}_{2}$ ekvivalento. Pažanga, kurią Lietuva, kaip ir kitos pasaulio šalys, pasiekè iggyvendindama Jungtinių Tautų Bendraja klimato kaitos konvencija (JTBKKK) bei Kioto protokolu nustatytus reikalavimus, fiksuojama kiekvienais metais pateikiamose į atmosferą išmetamų šiltnamio dujų apskaitos ataskaitose. Energetikos kompleksinių tyrimų laboratorijos

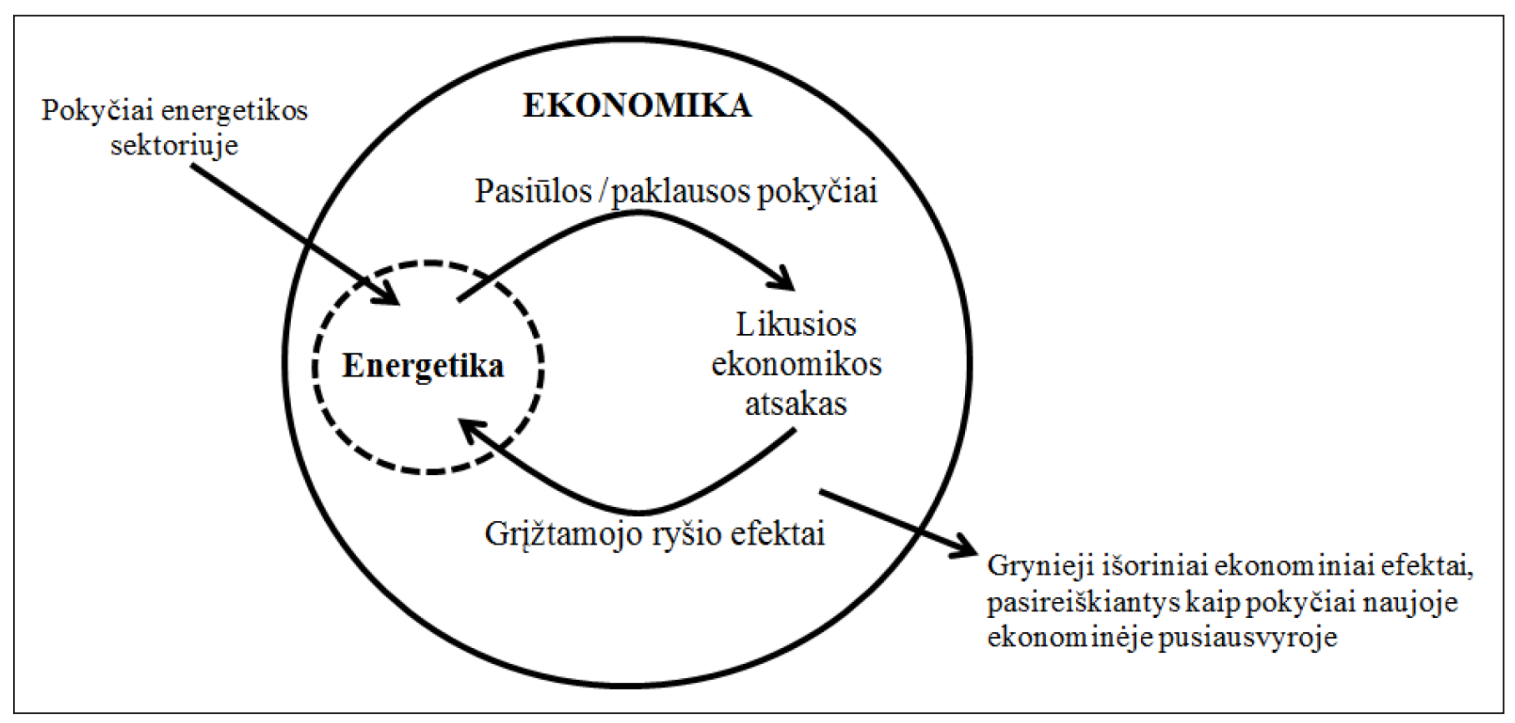

3 pav. Energetikos išorinių ekonominių efektų formavimasis 


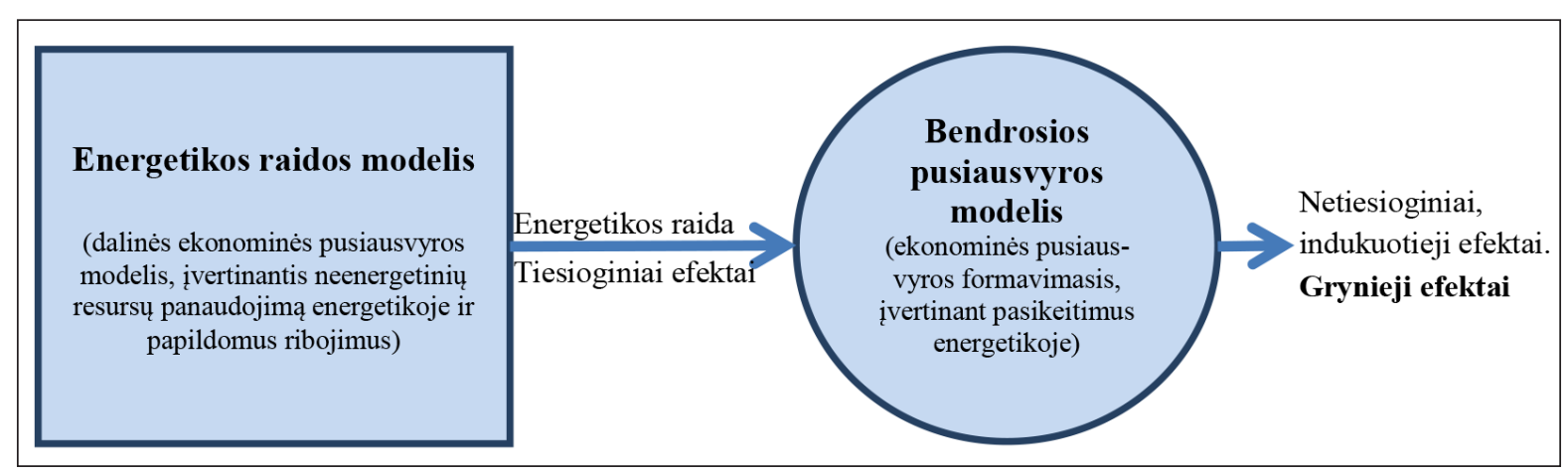

4 pav. Energetikos sektoriaus perspektyvines raidos išorinių ekonominių efektų vertinimas

ekspertai nuo $2011 \mathrm{~m}$. kasmet rengia nacionalines $\mathfrak{i}$ atmosferą išmetamų šiltnamio efektą sukeliančių dujų apskaitos energetikos sektoriuje ataskaitas. JTBKKK sekretoriatui pateikiamų duomenų patikimumui ir skaidrumui užtikrinti taikomi nacionaliniai emisijų rodikliai pagal deginamo kuro rūšis energijos gamybos sektoriuje ir kitose ūkio šakose, kurie periodiškai atnaujinami [20].

Sukaupta šiltnamio dujų emisijų apskaitos ir vertinimo patirtis tiesiogiai panaudojama apibrèžiant aplinkosaugos ribojimus, kurie taikomi sprendžiant energetikos sektoriaus raidos optimizavimo uždavini, taip įvertinant ES klimato kaitos švelninimo tikslų igyvendinimo galimybes. Kita vertus, Lietuvos galimybès prisidèti prie bendru klimato švelninimo pastangų, prisiimti ES kiekybiškai nustatytus rodiklius ar spręsti kitas aplinkosaugos problemas turi būti analizuojamos įvertinant specifinius šalies energetikos ir kitų ùkio šakų ypatumus. Tokios analizès svarbą patvirtino studijoje [21] atliktas $\mathfrak{i}$ atmosferą išmetamų šiltnamio dujų kiekio kitimo iki $2020 \mathrm{~m}$. prognozių ir Lietuvos galimybių sumažinti jų kieki $20 \%$ vertinimas. Šiuo tikslu buvo atlikta išsami energetikos sektoriaus anglies dioksido emisijų i atmosferą kitimo analizè taikant MESSAGE programinị paketą ir atsižvelgiant $\mathfrak{i}$ tikètinus energetikos sektoriaus raidos scenarijus.

\section{Praktinė energetikos plètros ir funkcionavimo} ilgalaikèje perspektyvoje modeliavimo patirtis Labai reikšminga studija [22], skirta naujos Visagino atominès elektrinès ribinei bloko galiai ivvertinti. Ši studija buvo rengta Lietuvos energetikos instituto Energetikos kompleksinių tyrimų ir Sistemų valdymo ir automatizavimo laboratorijose, bendradarbiaujant su Kauno technologijos universiteto specialistais. Remiantis bendrojo vidaus produkto pokyčiu ir elektros energijos naudojimo tendencijų tarpusavio ryšių Baltijos šalyse ir Lenkijoje analize, studijoje buvo parengta perspektyvinių elektros energijos poreikių ir maksimalių apkrovų Baltijos šalyse prognozè. Siekiant užtikrinti racionalų naujos atominès elektrinès ir visų trijų Baltijos šalių elektros energetikos sistemų darbą, jų raida ir funkcionavimas buvo optimizuojamas bendros sistemu raidos ir eksploatavimo mažiausių kaštų kriterijaus atžvilgiu. Analizè vykdyta taikant MESSAGE programinès įrangos pagrindu parengtą matematini modeli, kuriame įdiegtas originalus rezervinių galių modeliavimo principas ir kartu išspręsta rezervinių galių išdèstymo atskirose regiono elektrinèse problema. Studijoje nustatyta optimali perspektyvinė Estijos, Latvijos ir Lietuvos elektros energetikos sistemų generuojančių galių struktūra, jų darbo režimai, ịvertintos apsirūpinimo reikiamomis rezervinèmis galiomis (pirmine, antrine ir tretine) galimybès, elektros energijos importo-eksporto apimtys laikotarpiu iki 2045 m., įvertinant visus esamus ir būsimus ryšius su kontinentinès Europos, Skandinavijos šalių (Nordel) ir buvusios Sovietų Sąjungos (IPS/UPS) elektros energetikos sistemomis. Studijoje taip pat rekomenduoti Baltijos šalių elektros energetikos sistemų tarpusavio bendradarbiavimo principai, kurie gali būti reikšmingi siekiant užtikrinti reikiamas rezervines atsargas ir patikimą bei stabilų elektros energetikos sistemų darbą.

MESSAGE modelio lankstumo ir matematinès îrangos galimybès buvo sumaniai panaudotos 
studijoje [23], kurioje išsamus atsinaujinančių energijos ištekliụ panaudojimo galimybių ìvertinimas glaudžiai susietas su atskirų šalies administracinių regionų ypatumais. Šalies energetikos sektoriaus perspektyvinès raidos ir funkcionavimo matematinio modelio dalies, atskleidžiančios atsinaujinančių energijos išteklių panaudojimo galimybių modeliavimo principus, blokinè schema parodyta 5 pav. Atsinaujinančių energijos išteklių platesnio naudojimo galimybès pagrịstos nuoseklia visų galimų energijos srautu analize, pradedant nuo realiai galimų šalies išteklių išgavimo, įskaitant racionalų žemès naudmenų panaudojimą maistinių, pašariniu ir energetiniu augalu bei mišku auginimui, ir baigiant atskirų energijos rūšių, gautų iš šių

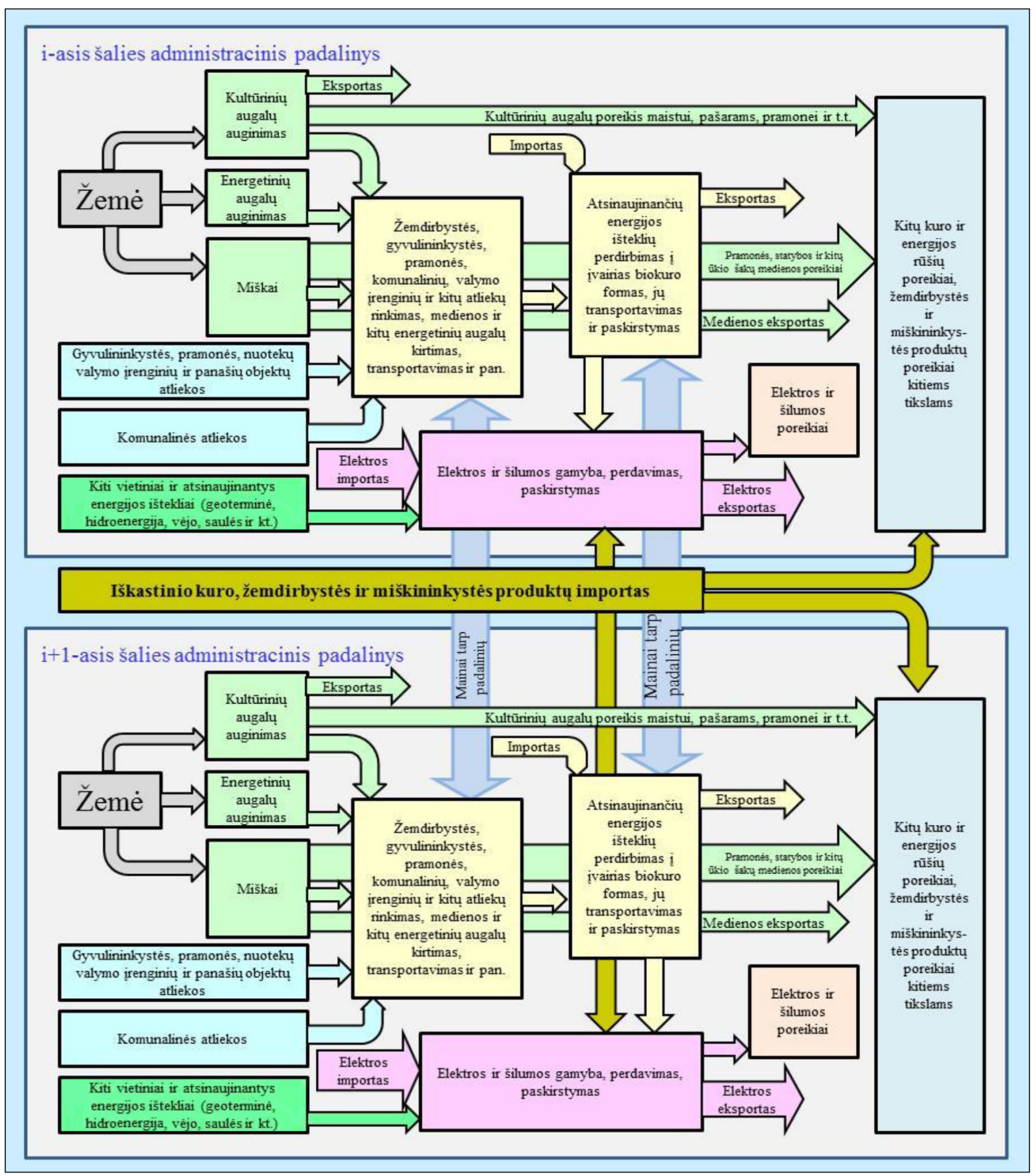

5 pav. Energetikos sektoriaus perspektyvinès raidos ir funkcionavimo matematinio modelio dalies, reprezentuojančios atsinaujinančių energijos išteklių tiekimą, schema 
išteklių, panaudojimu visuomenès poreikiams tenkinti. Be to, kompleksiškai buvo analizuojami visi vietiniai ir importuojami (ir galimi importuoti) energetinèms ir neenergetinèms reikmèms naudojami neatsinaujinantys energijos ištekliai. Studijoje nustatyta, kaip galima racionaliai patenkinti energijos vartotojų poreikius mažiausiomis suminèmis sąnaudomis, atsižvelgiant $\mathfrak{i}$ Lietuvos atsinaujinančių energijos išteklių potencialą, žemès ūkio ir miškininkystès galimybes, îsipareigojimus ES bei energetikos sektoriaus raidos strateginius tikslus.

Atskirų energijos išteklių panaudojimo apimtys ir ekonominis tikslingumas yra glaudžiai susiję su panaudojimo galimybėmis bei technologijų efektyvumu. Todèl studijoje [23] buvo išsamiai analizuojami visi galimi energijos ištekliai, pradedant jų gavyba ar importu, gamtinių išteklių perdirbimu ir transformavimu $\mathfrak{i}$ vartotojui tinkamas energijos rūšis, baigiant jų transportavimu iki vartotojų ir galutiniu panaudojimu. Sukurtas optimizacinis modelis parengtas orientuoto tinklinio grafo, kurio šakos parodo galimas technologijas ar procesus, o mazgai - atskiras energijos ar kitų produktų formas, pagrindu. Optimizacinis modelis realizuotas taikant MESSAGE programini paketą. Parengtas matematinis modelis suteikè galimybę kompleksiškai analizuoti per 60 skirtingų energijos rūšių ar produktų ir beveik 8000 technologijų bei procesų, o racionalaus energijos išteklių panaudojimo galimybès buvo analizuojamos ivvertinant atskirų savivaldybiu specifinius ypatumus. Taikant ši modeli galima nustatyti efektyvias diegtinas technologijas ir kiekvienos energijos išteklių rūšies panaudojimo apimtis tiek Lietuvoje, tiek ir atskirose savivaldybėse, jas pagrindžiant ekonominiu, aplinkosaugos, socialiniu ir kitais aspektais.

Pagal sutartị su LR Vyriausybės kanceliarija $2014 \mathrm{~m}$. parengta studija [13], kurios sudedamoji dalis buvo tyrimas dèl didelio naudingumo termofikacijos pletros ir centralizuotai tiekiamos šilumos sektoriaus raidos galimybių. Vykdant šiuos tyrimus, centralizuoto šilumos tiekimo sistema buvo nagrinèjama kaip sudètinè ir neatskiriama vieningo energetikos sektoriaus dalis, technologiniais ir energijos srautų ryšiais glaudžiai susijusi su elektros energetikos sistema, kuro tiekimo (ypač gamtinių dujų) ir kito- mis sistemomis. Centralizuoto šilumos tiekimo sistemų perspektyvinè raida ir funkcionavimas nagrinètas taikant šiam tikslui parengtą matematinị modelị. Modeliavimas suteikè galimybę nustatyti tolesnès biokuro panaudojimo ir termofikacinių elektrinių plètros tikslingumą šilumos ir elektros energijos gamybai didžiuosiuose miestuose ir šalies energetiniam saugumui, numatyti šilumos ir elektros energijos gamybos termofikacinèse elektrinèse, sunaudojamo kuro ir reikiamų investicijų apimtis. Atlikus analizę buvo pateikti pasiūlymai Nacionalinei šilumos ūkio plètros 2014-2020 m. programai. Galutinèje darbo ataskaitoje LR Vyriausybès kanceliarijai pateikta: šalies geopolitinès aplinkos analizé; energetikos strateginiai tikslai; ekonomikos raidos scenarijai ir su ekonomikos augimu susieti elektros energijos, centralizuotai tiekiamos šilumos ir tiesiogiai ūkio šakose sunaudojamo kuro perspektyviniai poreikiai; kuro kainų prognozès; energetikos sektoriaus esamos būklès analizė; jo raidos ir funkcionavimo ilgalaikèje perspektyvoje modeliavimo koncepcija; elektros energetikos sistemos ir centralizuoto šilumos tiekimo sistemų plètros kryptys; generuojančių galių, elektros ir šilumos gamybos bei sunaudojamo kuro struktūros kaitos dinamika; investicijų apimtys; teršalų išmetimai; ES paramos skirstymo principai ir racionalios paramos apimtys atskiroms technologijoms. Nuodugni ir ịvairiapuse Lietuvos energetikos sektoriaus raidos ir funkcionavimo scenarijų analizè ir optimizacinių skaičiavimo rezultatų apibendrinimas buvo svarbus etapas atnaujintai šalies Nacionalinès energetikos strategijai parengti.

Siekiant atnaujinti $2012 \mathrm{~m}$. patvirtintą Nacionalinę energetinès nepriklausomybès strategiją, 2015 m. LR Energetikos ministerijos užsakymu parengta studija [14], kurioje Energetikos kompleksinių tyrimų laboratorijos ekspertai suformulavo naują energetikos sektoriaus raidos ir funkcionavimo analizès koncepciją, atliko išsamią energetikos sektoriaus raidos laikotarpiu iki $2050 \mathrm{~m}$. analizę, j̇vertindami esminius pokyčius integracijos $\mathfrak{i}$ ES energetikos sistemas aspektu (pradètos eksploatuoti naujos jungtys LitPol Link ir NordBalt, veikia suskystintų ir gamtinių dujų terminalas, sustiprinta dujų tiekimo sistemos infrastruktūra ir kt.), naujas ES energetikos politikos nuostatas, aplinkosaugos ribojimus 
ir kitus reikšmingus vidaus ir išorès veiksnius. Atlikti tyrimai leido įvertinti realias Lietuvos galimybes prisidèti prie Konkurencingos mažo anglies dioksido kiekio technologijų ekonomikos sukūrimo iki 2050 m. plane ir Europos Komisijos komunikate „2020-2030 m. klimato ir energetikos politikos strategija" nustatytų tikslų igyvendinimo, optimaliai plètojant elektros energetikos ir centralizuotai tiekiamos šilumos sistemas, racionaliai panaudojant atsinaujinančių energijos išteklių plètros galimybes, gerokai padidinant energijos vartojimo efektyvumą. Remiantis matematinio modeliavimo rezultatu analize, nustatytos Lietuvos energetikos sektoriaus perspektyvinès raidos kryptys, racionalūs energetikos sektoriaus plètros ilgalaikèje perspektyvoje scenarijai ir apibendrinti pagrindiniai energetikos raidą apibūdinantys rodikliai. Šios studijos rezultatai, išsamiai juos išdiskutavus su energetikos ekspertais, asociacijomis, politikais ir visuomene, taps LR Vyriausybei tinkamu pagrindu pagrissti esmines šalies energetikos raidos strategines nuostatas ir teikti LR Seimui tvirtinti atnaujintą Nacionalinès energetikos strategijos projektą, kuriame apibrèžtos pagrindinès valstybès nuostatos dèl energetikos sektoriaus raidos laikotarpiu iki $2030 \mathrm{~m}$. ir gairès iki $2050 \mathrm{~m}$. Šios nuostatos ir kryptys pagrịstos ekonomiškumo, energetinio saugumo, energetikos poveikio šalies ekonomikai analize, aplinkosaugos ir valdymo tobulinimo aspektais, visapusiškai jas derinant su valstybès poreikiais ir naujausiais tarptautiniais reikalavimais.

Energetikos kompleksinių tyrimų laboratorijoje sukaupta ilgametė atliekamų energetikos sektoriaus raidos, taikant modernius perspektyvinio planavimo metodus ir kuriant naujus matematinius modelius, patirtis gali reikšmingai pasitarnauti Nacionalinès energetikos strategijos projekte numatyto energetikos kompetencijos centro ir ilgalaikio strateginio planavimo sistemos sukūrimui. Nuosekli ir lanksti Lietuvos energetikos sektoriaus kompleksinès analizès ir strateginio planavimo sistema, apimanti reikiamas valstybès institucijas, mokslo organizacijas, energetikos įmones ar asociacijas ir visuomenès institucijas, sukurtų pagrindą objektyviam, operatyviam ir veiksmingam atsakui $\mathfrak{i}$ energetikos srityje kylančius naujus iššūkius suformuoti. Nuolatinè stebėsena, atnaujinami matematiniai modeliai, reikiamų duomenų bazè ir profesionalūs tyrimai leistų sumažinti valstybès išlaidas, skiriamas atskiroms energetikos problemoms spręsti, užtikrintų energetikos politikos tęstinumą, padidintų siūlomų sprendimų objektyvumą ir pagrịstumą.

\section{IŠVADOS}

1. Esminiai mokslinių tyrimų energetikos strateginio planavimo srityje elementai yra bendro energetikos konteksto analizè ir perspektyviniu energijos poreikių nustatymas, energetikos sektoriaus raidos ir funkcionavimo modeliavimas bei platesnio energetikos poveikio vertinimas. Energetikos kompleksinių tyrimų laboratorijoje sukaupta ilgametė patirtis leidžia kokybiškai nagrinèti šiuos aspektus ir pasiūlyti racionalias rekomendacijas sprendimų prièmejjams.

2. Energetikos konteksto analizè apima aplinką, kurioje veikia energetika, pradedant nuo persipynusių ryšių su kitomis ūkio šakomis ir baigiant globalia aplinka bei vis daugiau reikšmès igyjančiais geopolitiniais veiksniais, kuro kainų kaita, energijos naudojimo tendencijas lemiančiu veiksnių analize ir perspektyvinių energijos poreikių prognozemis, aplinkosaugos ribojimais, energetikos politikos nuostatomis ir pan.

3. Per pastarajji dešimtmetị laboratorijoje atlikti energetikos sektoriaus, atskirų energetikos sistemu raidos ir funkcionavimo modeliavimo tyrimai buvo skirti reiškinių aprašymo adekvatumui didinti ir pasižymejo orientacija i praktinį mokslinių tyrimų pritaikomumą. Sukurta savita energetikos funkcionavimo ir raidos matematinio modeliavimo mokykla, išsiskirianti maksimaliai realistišku energetikoje vykstančių procesų atspindejimu matematiniuose energetikos planavimo modeliuose. Tai yra itin svarbu atsižvelgiant i pastaruoju metu pasaulyje vykstančias energetikos transformacijas (paskirstytosios generacijos pletra, sumanieji tinklai, energijos akumuliavimas vartotojų įrenginiuose ir pan.) ir sudaro prielaidas pakankamai adekvačiam naujų tendencijų bei technologinių sprendimų atspindejjimui matematiniuose modeliuose.

4. Platesnio energetikos poveikio tyrimai laboratorijoje buvo nukreipti it energetikos poveiki gamtinei ir ekonominei aplinkai - veiksnius, 
kurie turi įtakos ir pačios energetikos raidai. Sukurtas Lietuvos dinaminis bendrosios ekonominès pusiausvyros modelis leidžia kompleksiškai analizuoti energetikos raidos poveikị ịvairiems socialiniams ir ekonominiams rodikliams. Šis modelis gali būti sèkmingai pritaikytas ne tik energetikos, bet ir kitų ūkio šakų platesnio poveikio tyrimams.

5. Sukaupta ilgametė atliekamų energetikos sektoriaus raidos taikant modernius perspektyvinio planavimo metodus ir kuriant naujus matematinius modelius patirtis gali reikšmingai pasitarnauti Nacionalinès energetikos strategijos projekte numatyto energetikos kompetencijos centro ir ilgalaikio strateginio planavimo sistemai sukurti. Nuosekli ir lanksti Lietuvos energetikos sektoriaus kompleksinès analizès ir strateginio planavimo sistema sukurtų pagrindą objektyviam, operatyviam ir veiksmingam atsakui ị energetikos srityje kylančius naujus iššūkius suformuoti.

Gauta 20160630 Priimta 20160930

\section{Literatūra}

1. Miškinis V., Galinis A. Lietuvos nacionalinès energetikos strategijos gairès. Energetika. 2006. Nr. 3. P. 24-32.

2. Miškinis V., Galinis A., Vilemas J. Tyrimai energetikos sistemų optimizavimo srityje ir Nacionalinès energetikos strategijos evoliucija. Lietuvos mokslas, 61 knyga, Lietuvos energetikos institutas - 50. 2006. Vilnius. P. 70-106.

3. Miškinis V., Galinis A., Konstantinavičiūtè I. Challenges and options for development of the Lithuanian energy sector. International Journal of Global Energy Issues. 2010. Vol. 34. Iss. 1. P. 91-111.

4. Miškinis V. Energy demand forecasting in economies in transition. Energy Studies Review. 2002. Vol. 10. No. 2. P. 100-120.

5. Miškinis V., Konstantinavičiūtė I., Ušpuras E., Kaliatka A., Kopustinskas V. Neapibrèžtumo analizès taikymas energetikos ekonomikos vienmačių modelių uždaviniams. Energetika. 2006. Nr. 2. P. 1-9.

6. Miškinis V., Vilemas J., Konstantinavičiūtè I. Analysis of energy consumption and energy intensity indicators in Central and Eastern European countries. Energy Studies Review. 2006. Vol. 14. No. 2. P. 171-188.

7. Miškinis V., Baublys J., Konstantinavičiūte I., Lekavičius V. Aspirations for sustainability and global energy development trends. Journal of Security and Sustainability Issues. 2014. Vol. 3(4). P. 17-26.

8. Miškinis V., Galinis A., Konstantinavičiūtė I., Lekavičius V. Energijos vartojimo Lietuvoje ir ES šalyse tendencijos. Energetika. 2014. T. 60. Nr. 2. P. 96-112.

9. Miškinis V., Baublys J., Konstantinavičiūtè I., Lekavičius V. Energy efficiency as precondition of energy security. Journal of Security and Sustainability Issues. 2015. Vol. 4. No. 3. P. 197-208.

10. Europos Parlamentas ir Europos Sąjungos Taryba (2009). Direktyva dèl skatinimo naudoti atsinaujinančių išteklių energiją, iš dalies keičianti bei vèliau panaikinanti Direktyvas 2001/77/ EB ir 2003/30/EB, (2009/28/EB), L 140/16.

11. Europos Parlamentas ir Europos Sąungos Taryba (2012). Direktyva dèl energijos vartojimo efektyvumo, kuria iš dalies keičiamos direktyvos 2009/125/EB ir 2010/30/ES bei kuria panaikinamos direktyvos 2004/8/EB ir 2006/32/ EB, (2012/27/EB). http://eur-lex.europa.eu/ legal-content/LT/TXT/HTML/?uri=CELEX:32012L0027\&from $=\mathrm{LT}$

12. Konkurencingos mažo anglies dioksido kiekio technologijų ekonomikos sukūrimo iki $2050 \mathrm{~m}$. planas. Briuselis, 2011. http://ec.Europa.eu/cli$\mathrm{ma} /$ policies/roadmap/index_en.htm

13. Lietuvos energetikos sektoriaus perspektyvines plètros analize atsižvelgiant i ES strategines iniciatyvas energetikos srityje: galutinè ataskaita. Lietuvos energetikos institutas, 2014 (vadovas A. Galinis).

14. Lietuvos energetikos sektoriaus pletros tyrimas: galutinè ataskaita. Lietuvos energetikos institutas, 2015 (vadovas A. Galinis).

15. Model for Energy Supply Strategy Alternatives and their General Environmental Impact (MES$S A G E$ ). International Atomic Energy Agency, Vienna, 2003. 246 p.

16. Galinis A., Miškinis V., Vilemas J., Tarvydas D. Analyses of energy supply options and security of energy supply in the Baltic States. IAEA Technical Documents, Vienna, 2007. 324 p. 
17. Ateities technologiju optimalaus integravimo $i$ energetikos sektoriu metodologijos sukūrimas: galutinė ataskaita. Lietuvos energetikos institutas, 2012 (vadovas A. Galinis).

18. Energetikos sektoriaus raidos išoriniai ekonominiai efektai: kiekybinis vertinimas: tarpinè ataskaita. Lietuvos energetikos institutas, 2015 (vadovas A. Galinis).

19. Energetikos raidos scenariju socialinio ir makroekonominio poveikio vertinimas: galutinè ataskaita. Lietuvos energetikos institutas, 2015 (vadovas V. Lekavičius).

20. Šiltnamio efektą sukeliančių dujų nacionalinių emisijų rodiklių energetikos sektoriuje atnaujinimas: galutiné ataskaita. Lietuvos energetikos institutas, 2016 (vadovè I. Konstantinavičiūtè).

21. Išmetamų ị atmosferą šiltnamio dujų kiekio kitimo iki 2020 m. prognoziu ir Lietuvos galimybiu, igyvendinant prisiimtus isipareigojimus 20 proc. sumažinti šiltnamio duju kieki iki 2020 m., j̣vertinimo ir pasiūlymu parengimas: galutinè ataskaita. Lietuvos energetikos institutas, 2007 (vadovas V. Miškinis).

22. Didžiausios vienetinès galios Lietuvos elektros energetikos sistemoje galimybiu tyrimas: galutinè ataskaita. Lietuvos energetikos institutas, 2009 (vadovai A. Galinis, V. Radziukynas).

23. Šalies savivaldybėse esamų atsinaujinančių energijos išteklių (biokuro, hidroenergijos, saulès energijos, geoterminès energijos) ir komunalinių atliekų panaudojimas energijai gaminti: galutinè ataskaita. Lietuvos energetikos institutas, 2009 (vadovas A. Galinis).
Vaclovas Miškinis, Arvydas Galinis, Inga Konstantinavičiūtė, Vidas Lekavičius, Dalius Tarvydas

\section{MATHEMATICAL MODELLING AS THE FOUNDATION FOR THE STRATEGIC ENERGY PLANNING}

\section{Summary}

A comprehensive analysis of the final energy consumption trends, preparation of energy demand forecasts and application of modern energy planning methods and mathematical models are very important stages of energy research directed to the preparation of studies on future development and operation of the energy sector and strategic energy policy documents as well as for the justification of rational energy development provisions. The aim of this paper is to summarise experience of the Laboratory of Energy Systems Research on energy planning, to present some findings from the major studies on long-term development and operation of the energy sector and separate energy systems and to discuss the role of mathematical modelling tools focused on the creation of the strategic energy planning system taking into consideration a necessity to meet ambitious goals of the EU on the deployment of renewable energy sources and requirements of climate mitigation policy, to react to global challenges.

Keywords: mathematical modelling, energy sector development, strategic energy planning, final energy, energy demand forecasting, energy policy 